\title{
NATURE'S CONTRACEPTIVE. WET-NURSING AND PROLONGED LACTATION: THE CASE OF CHESHAM, BUCKINGHAMSHIRE, $1578-1601^{1}$
}

by

\section{DOROTHY MCLAREN*}

What, could she, as her own existence dear,

Nine tedious months her tender burthen bear,

Yet when at length it smil'd upon the day,

To hireling hands its helpless frame convey.

(William Roscoe, The nurse, 1798. Translated from Luigi Tansillo, 1510-1596.)

\section{SUMMARY}

The evidence for a modal class of birth intervals during the Stuart period in south Oxfordshire presented itself through the family reconstitution of the parishes of Caversham and Mapledurham. This pattern is becoming quite clear from a family reconstitution of the busy port of Minehead, Somerset, during the same period. The work is being funded by the Social Sciences Research Council.

Searches for qualitative evidence to support the quantitative evidence from the parish registers indicated that the prolonged lactation which caused the modal two to three years intergenesic interval was not confined to one mother and one baby.

Real evidence for a substantial amount of wet-nursing was not found in Caversham, Mapledurham, or in Minehead. It was found in Chesham, Buckinghamshire, at the end of the Tudor period. The article that follows is an extension to 'Fertility, infant mortality and breast feeding in the seventeenth century', published in Medical History, 1978, 22: 378-396. There is nothing conclusive in the new article, it is merely a start to the understanding of wet-nursing in England.

THERE Is No doubt that in the past upper-class women thought themselves degraded if they suckled their babies, and it was very exceptional for women of rank to breast feed. Lady Falkland and Elizabeth Willoughby ${ }^{2}$ certainly did. The Duchess of Lincoln ${ }^{3}$

${ }^{1}$ Version of a paper read at a seminar at University College London, on 1 November 1978 for Dr. W. F. Bynum-Seminars in the History of Science and Medicine.

*D. M. McLaren, B.A., Ph.D., Research Fellow, University of Exeter, History Department. I am indebted to Jane Evans, B.Sc., Ph.D., Division of Genetics, Department of Paediatrics, Childrens Centre, Winnipeg, Manitoba, for aid with the statistical analysis contained in this article, and to Joan Thirsk, Reader of Economic History, University of Oxford, for her endless patience and advice.

' Lady Falkland was born in 1585 or 1586; she married at the age of fifteen, but no children were born for seven years. When her married daughter, with whom she was travelling back from Ireland gave birth to a daughter prematurely, Lady Falkland "was resolved to have nursed her daughter's child together with her own, not yet weaned". Her own youngest child was still at her breast. The 


\section{Nature's contraceptive}

and the Duchess of Devonshire 4 also spring to mind, but these were very enlightened and defiant women. Clearly by the end of the Elizabethan period some mothers of lesser rank were beginning to emulate the custom of the nobility, and it was said, "tis oftner the sinne of the Higher and richer sort, than of the meaner, and poorer, except some nice and prowd idle dames, who will imitate their betters, till they make their husbands beggars. And this is one hurt which the better ranke doe by their ill example, egge, and imbolden the lower ones to follow them to their losse. . . I am sure we have more helpes to performe it and have fewer probable reasons to alleage against it, than women that live by hard labour, and painful toile". ${ }^{5}$ In spite of these sorts of pleas, most upperclass women sent their newly-born infants out to a wetnurse, often for up to three years. ${ }^{6}$ Women who were very wealthy or of exceptionally high status, mostly royalty, brought the wet-nurses into the home, but this was a rare occurrence.

The overall numbers of births, even for a unit as small as the parish, entirely masks the enormous differences in the fertility of upper-class women and women who had to breast feed their own babies. However, recent studies of the family all indicate that in pre-industrial England, fewer children were born to poor parents ${ }^{7}$. The average age of menarche was older than it is today ${ }^{8}$ and the average age of menopause was generally younger than it is today. If a marriage contained twenty child-bearing years for a mother, it is clear that the aristocratic, and often gentle, mother was at risk for twenty pregnancies. Eighteen pregnancies is not uncommon, ${ }^{9}$ and is getting

premature grandchild was not suckled by Lady Falkland, as both daughter and grand-daughter died of the delivery. The Lady Falkland: her life, by her daughter, London, Rambler, 1861, pp. 24-25. Elizabeth Willoughby's breast feeding experiences were covered in Dorothy McLaren, 'Fertility, infant mortality, and breast feeding in the seventeenth century', Med. Hist., 1978, 22: 378-396.

3 The duchess of Lincoln regretted that she had not suckled her own infants. Eighteen were born, and some died at wet-nurse. She wrote a treatise to women to suckle their own infants and dedicated it to her daughter-in-law who was breast feeding her baby, because, as she said, "your rare example ... . that loving act of a loving mother in giving the sweete milke of your own breasts, to your owne childe", from, The Countess of Lincoln's nurserie, 1622, Bodleian library, Oxford, pamphlet 40/19. Art.

- William Roscoe, The nurse, translated from Luigi Tansillo (1510-1596) in the notes to the 1804 edition, p. 27. "That example which the Italian poet could only wish for, this country has experienced in the conduct of the duchess of Devonshire, she though moving in the most elevated sphere of society . . . in defiance of custom and in contempt of unfeeling fashion, she persevered in the performance of this indispensable duty, and is said to have found her reward in the great resemblance both in constitution and disposition between the child she nursed and herself." See also, V. Foster, The two duchesses, London, Blackie, 1898, p. 12.

- The Countess of Lincoln's nurserie, op. cit., note 3 above.

- Lloyd de Mause (editor), The history of childhood, London, Souvenir Press, 1974, pp. 35-39.

7 C. W. Chalklin, Seventeenth century Kent: a social and economic history, London, Longmans, 1965, pp. 35-38. J. D. Chambers, Population, economy, and society in pre-industrial England, London, Oxford University Press, 1972, p. 70. P. Laslett, The world we have lost, London, Methuen, 1971, p. 66. L. Stone, Family, sex and marriage in England 1500-1800, London, Weidenfeld \& Nicolson, 1977, p. 64. N. L. Tranter, 'Demographic change in Bedfordshire, 1670-1800', unpublished Ph.D. thesis, University of Nottingham, 1966.

B R. E. Frisch, 'Demographic implications of the biological determinants of female fecundity', Social Biology, 1975, 22: 19-20, "if menarche occurred at age 15-16, the fitness for procreation was reached at age 22, the ages best suited for procreation were $25-29$, and the average at last birth was 41-42," (England and Scotland findings 1850-1870).

- Countess of Lincoln's nurserie, op. cit., note 3 above. Stone, op. cit., note 7 above, p. 63, R. V. Schnucker, 'Elizabethan birth control', J. interdisciplinary Hist., 1975, 4: 666. Dictionary of national 


\section{Dorothy McLaren}

close to the physiological maximum for most women. Ann Hatton, sole heiress of a wealthy family, who married Daniel Finch, is said to have had thirty children, "Five sons and eight daughters, beside ten who died young, and seven infants stillborn".10 This must be an exceptional case. In many maternal histories it would be impossible to squeeze in another pregnancy, but it must be borne in mind that family reconstitutions and genealogical tables do not contain spontaneous abortions and may not contain still births. This does not, of course, alleviate the fecundity of women of high rank. In fact, it makes it even higher than it at first appears.

Many aristocratic women towards the end of their child-bearing years obtained respite from annual pregnancies as their advanced age prevented ovulation taking place as often. However, annual pregnancy is often confirmed by the numbers of wealthy women who died early in their marriages, but had produced, for example, six children in six years. Among women of high rank therefore, it is likely that, after a suitable lying-in period dependent on the strength or whim of the mother; having parted with her young, she was like a brood mare, immediately ready for another conception. Small wonder that the most revolting means of artificial contraception were sought by Elizabethan women. ${ }^{11}$ Unfortunately for them, they did not work.

Theoretically then, being unwilling to suckle their infants and lacking reliable artificial contraceptives, upper-class women could expect an annual pregnancy, whether or not it went to full term, throughout most of their child-bearing period. Can we prove this? Quantitative analysis has not yet been attempted with such families and it cannot be undertaken here. ${ }^{12}$ The evidence for annual pregnancy is therefore entirely qualitative, but it is strong. The diaries of aristocratic women are often filled with horrendous tales of unwanted pregnancies and difficult deliveries. The appalling fecundity of the Lady Anne Clifford has been written about elsewhere. ${ }^{13}$ Other notable examples include the family of Sir Robert Drury of Hawstead. ${ }^{14}$ Robert married Audrey Rich, the daughter of the Lord Chancellor, and nine children were born between 8 November 1544 and 27 August 1552. One set of twins was born on 30 March 1550. There were, therefore, eight confinements in less than eight years. The lord of the manor of Luccombe and other Somerset manors married a widow in 1562. Katherine, now the wife of John Arundell, bore him eight children in eight years and died giving birth to her last child. John soon remarried, and his second

biography, Samuel Wesley, "Of his nineteen children ... [ten] survived infancy". These were of one wife Susanna née Annesley. It is said that all the daughters of Samuel and Susanna Wesley were highly educated and had great ability. But Martha, for instance, buried nine out of her ten children in infancy. Mrs. Frances Crockford of Minehead, Somerset, see note 19 below. Finally, Queen Anne would have reached eighteen pregnancies with her spontaneous abortions.

${ }^{10}$ Charlotte Fell Smith, Mary Rich, Countess of Warwick 1625-1678, her family and friends, London, Longman, Green, 1901, p. 303.

${ }^{11}$ Schnucker, op. cit., note 9 above.

12 T. H. Hollingsworth, 'A demographic study of the British ducal families', in D. V. Glass and D. E. C. Eversley (editors), Population in history, London, Edward Arnold, 1974, pp. 354-378. This writer has examined the fertility of the aristocracy but is not especially concerned with birth intervals.

18 McLaren, op. cit., note 2 above, p. 381.

14 R. N. Swanson, 'A Tudor family bible in a university library', Genealogists' Mag., 1974, 17: 10, 550-552. 


\section{Nature's contraceptive}

wife Gertrude produced four children in the first four years of their marriage. ${ }^{15}$

Anne, the wife of Sir George More, bore him nine children between 1581 and 1590 , she too died giving birth to the last of her children. One of the daughters of this marriage, also called Anne, married the poet John Donne. Like her mother she was appallingly fertile and twelve children were born between 1602 and 1617. Anne Donne, née More also died giving birth to her last child; she was thirty-three years old, and on this rare occasion we know from the letters of John Donne that at least one spontaneous abortion occurred in addition to her twelve other pregnancies. ${ }^{16} \mathrm{We}$ shall hear more of the family of Whitelocke later, but it is apposite to state here that between 1635 and 1647 Frances Whitelocke bore nine children. Bulstrode Whitelocke married again soon after Frances died, and his third wife Mary bore him seven children in eight years. Alice Thornton's maternal experiences have been written about elsewhere. Her father was Lord Deputy of Ireland. Alice had nine children between 1652 and 1667, but the first five children were born in the first five years of her marriage. ${ }^{17}$ When Sir Anthony Craven and his wife arrived at the manor house at Caversham in Oxfordshire, after the Restoration, they already had an established family. Five more children were born in five years, and three more, at least, were to arrive before the family left Caversham in 1677. Many of these infants perished, so no wonder it was written that, "The flowering Cravens scarce had time to fall". ${ }^{18}$

Frances Crockford was not of noble birth, but the family was very wealthy. Frances gave birth to eighteen live children in her twenty-six child-bearing years. Only one interval was more than two years, and one set of twins was born. However, Frances Crockford was particularly unlucky in attempts to give her husband Samuel an heir, and two Samuels were buried within weeks of their baptisms. The third Samuel was baptised on 9 March 1665. This Samuel was her tenth child and he appears to have survived. This Somerset family was influential and very involved with the parish church. The child-bearing span from 1652-1678 was one of good registration in their parish of Minehead, and it seems unlikely that their vital statistics are missing or incorrect. ${ }^{19}$

Susan, the wife of Walter Kirsell of Mapledurham, Oxfordshire, gave birth to six children in less than six years between 1670 and 1676. Susan died giving birth to her last child. ${ }^{20}$ In the neighbouring parish of Caversham, Elizabeth, the wife of the wealthiest man in the parish bore nine children in less than eleven years to her husband, William Berry. ${ }^{21}$ Numerable other examples of extremely fertile upper-class

\footnotetext{
${ }^{15}$ For the family tree of John Arundell and other west Somerset families see C. E. H. ChadwyckHealey, The history of part of west Somerset, London, Southeran, 1901.

${ }^{16}$ Mary Clive, Jack and the doctor, London, Macmillan, 1966, p. 65.

17 McLaren, op. cit., note 2 above, p. 386.

18 Dorothy McLaren, 'Stuart Caversham: a Thames-side community in Oxfordshire during the seventeenth century', unpublished Ph.D. thesis, University of Reading, 1975, p. 179.

10 The family of Samuel and Frances Crockford is in the sample of complete families with six or more confinements (1640-1680). This sample is part of the data collected from the parish registers of the port of Minehead, Somerset, during the Stuart period. See McLaren, op. cit., note 2 above, p. 395 , note 70 .

${ }^{20}$ Mrs. Susan Kirsell of Mapledurham, Oxfordshire, is typical of this situation. Six infants were born between August 1670 and April 1676, when Susan died soon after her sixth child was delivered.

${ }^{21}$ Mr. William Berry appeared to be the wealthiest man from the south Oxfordshire probate
} 


\section{Dorothy McLaren}

women in England could be given but space does not permit.

The obvious question we must ask, is why did aristocratic and gentle women produce so many more infants than poor women? It is quite clear from studies in progress that their expectation of life was not longer than that of rural poor women of their time, even though their child-bearing span may have been slightly longer. The evidence seems overwhelming that the answer is to be found in their refusal to use nature's contraceptive, prolonged lactation.

The only reasonable alternative to maternal suckling was breast feeding by another "teeming" woman and there is considerable evidence that this course was usually followed. However, we have little information for pre-Industrial England on the usual length of the suckling period. Sabine Johnson was said to have been thirty-four months old when she was weaned. Sabine herself wrote to her husband, "Charyte is weaned and is come home", 22 but it is clearly not possible to say for how long she was solely at the breast. Although Ralph Freke was thought to have been born dead after a very trying delivery and had a surgeon attending him daily for six weeks, he was put out to wet-nurse at ten weeks. Clearly, from her diary Elizabeth Freke was concerned about her son and shocked at his condition on more than one occasion, but she did not remove him from wet-nurses in time to prevent serious physical problems arising whilst she was absent. ${ }^{23}$ John Cannon's father was the bailiff of the Lord Lieutenant of Bath. John's christening ceremony was held when the Lord Lieutenant kept his Court Baron, and there was great rejoicing and mirth for a day or two. Soon after he was, "put to Nurse to one Sussanah the wife of one George Ivyleaf a husbandman in the same parish who had several children", and the diary of John Cannon clearly states that all the children in the family were nursed by other women. ${ }^{24}$

Elizabeth Bulstrode, the daughter of Edward of Hedgerly Bulstrode, Buckinghamshire, married Judge James Whitelocke on 9 September 1602 at Beaconsfield. Seven live babies were born between 6 October 1603 and 17 May 1612. It is with the eldest son of this marriage that we are concerned, and I am indebted to Dr. Joan Thirsk for leading me to the diary of Bulstrode Whitelocke. He was born on 6 August 1605 in Fleet Street and christened at St. Dunstan's-in-the-West on 19 August, 1605 , "and in convenient time he was sent to be nursed at Woburn in Bucks, near the friends of his mother". By the year 1607, the "child at nurse was not well dieted, nor carefully looked unto; but began thus early to endure hardship, which, being found out by his vigilent mother, she soon after removed him to her own house, and weaned him". Bulstrode's first wife Rebecca had one child James and she died when he was three years old. James was also nursed at Woburn and his grandfather

inventories of the seventeenth century. Apart from the greatest stock of animals and most extensive crops in store and growing, he alone left "silver" in the house. McLaren, op. cit., note 18 above, appendix, p. 28.

${ }_{22}$ I am indebted to Dr. Joan Thirsk for references to Sabine Johnson, see also, de Mause, op. cit., note 6 above, p. 36.

${ }^{23}$ Mary Carbery (editor), Mrs. Elizabeth Freke her diary 1671-1714, Cork, Ireland, Guy, 1913, p. 25.

24 The diary of John Cannon, Somerset Record Office, DD/SAS C/1193. I am indebted to Mr. Robin Bush of the Somerset Record Office for bringing this diary to my notice. 


\section{Nature's contraceptive}

went to see the baby there and sang songs in the nurse's house. When James was more than two years old his mother "was content to be living at Fawley Court, being near to her child at nurse at Woburn". ${ }^{25}$

Six months after Rebecca had been buried, Bulstrode Whitelocke married Frances Willoughby. We have already noted that Frances bore nine live babies in twelve years. Although her sister-in-law, Elizabeth Willoughby, certainly did suckle her own babies, it seems unlikely that she was able to persuade Frances to follow her example. ${ }^{26}$ It is the feeding habits of the Whitelocke infants that have led to this current investigation. The parish of Woburn was a plurality with Chesham, also in the county of Buckinghamshire. ${ }^{27}$ Moreover, Frances Willoughby was reared near Chesham. The parish registers of Chesham have survived and one has been printed. J. C. Cox, a gatherer of useful facts of history, noted that many children were brought to Chesham to be nursed. He repeated what the editor of the Chesham parish register had said about the nurse children of London and hinted at sinister motives for their removal from London. ${ }^{28}$ It is possible that there was insufficient concern for some of the children who went to Chesham, but it is difficult to think that they were abandoned, as the names of the children and often the names of their parents were recorded.

There is no evidence yet of any financial contracts for Chesham foster mothers. However, we are not here concerned with who paid for the nursing service or, in fact, who brought the infants to Chesham. We are concerned with to whom they went to be suckled. The fact that some nurse children perished and were buried in Chesham is the only indication we have that they were there at all. The number of these children who perished would suggest that they were only a percentage of those who came to be nursed, and thus it seems clear that wet-nursing was an organized social institution.

This was not simply haphazard wet-nursing. The number of nurse children mentioned in the Chesham register between 1578 and 1601 was thirty-seven, all burials. The French experience of wet nursing, ${ }^{29}$ and the remarks of Archbishop Tillotson in England in the seventeenth century, ${ }^{30}$ suggest that perhaps as many as four-fifths of children sent to wet nurse died at a very early age. The physician Haines, too, was very shocked by the numerous deaths of infants sent to nurse twelve miles from London. ${ }^{31}$ The number of nurse children buried in Chesham is, therefore, not a large number but it could have represented a fairly high percentage of the infant population of this parish. It is also clear from the sample that a considerable number of the women in Chesham were acting as wet-nurses. What effect, we must ask, did this have on their fertility?

\footnotetext{
${ }^{25}$ McLaren, op. cit., note 2 above, p. 387, and Ruth Spalding, The improbable puritan: a life of Bulstrode Whitelocke, London, Spalding, 1975.

${ }^{26}$ See note 2 above.

${ }^{27}$ For a background to Chesham, Buckinghamshire, see William Page (editor), The Victoria history of the counties of England: a history of Buckinghamshire, 111, 1925. Clive Birch, The book of Chesham, Chesham, Baracuda, 1975. G. J. Smith, A chat about Chesham, Chesham, Smith Bros., 1903.

88 J. C. Cox, The parish registers of England, London, Methuen, 1910, pp. 67-69.

29 A. Chamoux, 'Town and child in eighteenth century Rheims', Local popul. Stud., 1974, 13: 45-46. Edward Shorter, The making of the modern family, London, Collins, 1976, pp. 168-204.

${ }^{30}$ Archbishop John Tillotson, Sermons, vol. 3: 'Concerning the education of children', first written 1694, 1720 edition, p. 524.

${ }^{31}$ W. S. Craig, Child and adolescent life in health and disease, Edinburgh, Livingstone, 1946, p. 42
} 


\section{Dorothy McLaren}

\section{TABLE I}

Reconstituted families of Chesham, Buckinghamshire, 1578-1601, who nursed children from London and Oxford. Their birth intervals in weeks.

\begin{tabular}{|c|c|c|c|c|}
\hline \multirow[b]{2}{*}{ Mean interval } & \multicolumn{3}{|c|}{ Birth order } & \multirow[b]{2}{*}{ Total intervals } \\
\hline & $1-2$ & $\begin{array}{l}2-3 \\
3-4 \\
4-5\end{array}$ & $\begin{array}{l}5-6 \\
6-7 \\
7-8 \\
8-9\end{array}$ & \\
\hline $\begin{array}{l}\text { A. 1st child survived; no } \\
\text { nurse child taken }\end{array}$ & $\begin{array}{l}127.0 \\
(13)\end{array}$ & $\begin{array}{l}141.5 \\
(33)\end{array}$ & $\begin{array}{l}135.6 \\
(11)\end{array}$ & $\begin{array}{l}137.1 \\
(57)\end{array}$ \\
\hline $\begin{array}{l}\text { B. 1st child survived; } \\
\text { nurse child taken }\end{array}$ & $\begin{array}{l}231.3 \\
(3)\end{array}$ & $\begin{array}{l}317.7 \\
(6)\end{array}$ & $\begin{array}{l}252.6 \\
(4)\end{array}$ & $\begin{array}{l}277.7 \\
(13)\end{array}$ \\
\hline $\begin{array}{l}\text { C. 1st child died in less than } \\
\text { two years; no nurse child } \\
\text { taken }\end{array}$ & $\begin{array}{l}71.4 \\
(4)\end{array}$ & $\begin{array}{l}101.1 \\
(6)\end{array}$ & $\begin{array}{l}128.3 \\
(6)\end{array}$ & $\begin{array}{l}103.9 \\
(16)\end{array}$ \\
\hline $\begin{array}{l}\text { D. 1st child died in less than } \\
\text { two years; nurse child taken }\end{array}$ & $\begin{array}{l}97.0 \\
(1)\end{array}$ & $\begin{array}{l}152.5 \\
(3)\end{array}$ & $\begin{array}{l}292.0 \\
(1)\end{array}$ & $\begin{array}{l}169.3 \\
(5)\end{array}$ \\
\hline \multicolumn{4}{|c|}{ Numbers in parentheses indicate number of cases. } & \\
\hline
\end{tabular}

It can be seen that the interval when no nurse child was taken but the child survived two years was approximately two and a half years for the first interval rising to approximately two years and nine months for later intervals.

If a nurse child was taken the intervals were doubled indicating that prolonged suckling of another newborn infant caused a lengthening of the interval.

When the first of two children died the interval fell at all birth orders but was shortest at the earlier birth orders. These intervals were however increased again and were close to the figures for when a child survived and a nurse child was taken (B).

There were twenty-one families in the sample. 112 confinements, one set of twins, hence 113 natural children. The infant mortality of the natural children was 226 per thousand live births. There were 91 total intergenesic intervals used.

The term, "wet-nurse" is not used in the Chesham register. It is, therefore, important to define what we mean by "nurse", which is the term used. It would have been strange to find the term, "wet-nurse" in the period under review, as it was not coined until 1620. Before then, the term, "his nurse", meant the woman who was giving him suck. In this case these were the "teeming"32 women of Chesham, in the process of rearing infants to whom they had given birth.

In some cases it is clear that a nurse child was taken when a natural child had died, and sometimes when a family had been reared. Table $I$ is self-explanatory regarding the results of the analysis of the Chesham foster mothers. In some cases it appears possible that when an infant died a nurse child was taken supposedly to reduce the risk of what they called "milk fever". It is equally likely that a nurse child was taken

22 The shorter Oxford English dictionary on historical principles, Oxford, Clarendon Press, 1973, p. 2530 'wet nurse', p. 2253 'teeming'; and see also an elegy to Dr. Willis, printed in Oxford in 1675, "No sooner has the Teeming womb, prepared her Burthen for another room, but now the infants born and cries Complains a little while and dies", Bodleian Library, Oxford, Wood 429.45. 


\section{Nature's contraceptive}

to avert an early pregnancy and obtain an income. This must be especially true when a nurse child was introduced after a successful family had been raised and further children were unwanted. It would have been a good economic proposition to take a nurse child from London or Oxford for a fee. Rich or poor, born in or out of wedlock, these nurse children were as important to the women who suckled them as they were to their natural parents.

Chesham register starts in $1538 .^{33}$ From 1538 to 1574 no nurse children are mentioned. In the burial register in 1575 one nurse child was laid to rest, and two in 1576. In 1577 three named nurse children were buried. It was not recorded to whom these nurse children were taken to be suckled. All the women in the sample have three things in common: first, they were wives of Chesham men with an established home in the Chesham parish between March 1578 and July 1601 ; second, they were all producing infants between these dates; and third, they all buried one or more nurse children. Not every woman who buried a nurse child in Chesham is in the sample. Joan and Elizabeth Randoll, for example, both buried nurse children, they are not in the sample because both of their husbands were called John and it has been impossible to reconstitute the Randoll nursing mothers without ambiguity. Christian Pegsworth, who married Richard Dell on 30 July 1571, cannot be used because Richard Dell was a common name in Chesham. The wife of Henry Ward and the widow Taylor took nurse children, but it was impossible to reconstitute their families. It must be emphasized that many more Chesham women than those in the sample may have been taking children to nurse during this period. If they did so, they were more successful than the foster mothers in the sample. If they were not successful and the infants did perish, they were not buried in Chesham. It is possible that some parents took their dead infants home to be buried.

It is clear from the sample that the women who suckled the nurse children from London and Oxford were by no means the dregs of the female society of Chesham. The occupations of about half of the husbands of the foster mothers at this time are known from the parish register. At least four of the husbands were known as turners, trencher-makers, and shovel-makers; this is not surprising, as Chesham was well known in the Buckinghamshire Chilterns for wood-turning. In addition, two husbands were tailors, two were weavers, and there was a glover, a miller, and a labourer. Some of the remainder of the husbands whose occupations are not stated, did have a number of "servants". This does perhaps indicate, that, whilst not gentlefolk, they were above the status of labourers.

Most of the foster mothers buried one nurse child, occasionally two, but Anne, the wife of Richard Smythe, the glover, buried four nurse children, three of them in eight months. At a later date Anne Smythe may not have been officially allowed to take children to nurse, "the Foundling Hospital ... had a strict rule that any nurse who had buried two children, was never allowed to imperil the life of a third". ${ }^{34}$ Anne was an Edwards girl from a family of shovel- and trencher-makers before she married Richard

38 J. W. Garrett-Pegge, A transcript of the first volume, 1538-1636 of the parish register of Chesham in the county of Buckingham, London, Eliot Stock, 1904.

34 Ivy Pinchbeck and Margaret Hewitt, Children in English society, vol. 1, University of Toronto Press; London, Routledge \& Kegan Paul, 1972, p. 185. 


\section{Dorothy McLaren}

Smythe. Three wives of Edwards men, all involved in wood-turning, each buried a child between 1578 and 1601 , and are therefore in the sample. These were not the only close relationships within the sample. They were almost all seen to be related by birth or marriage. Both genetic and environmental influences may have contributed to their abilities to breed and suckle children well. It is unlikely, that in a period before sterile milk, they could have been successful in rearing their own babies without adequate breast milk. Unlike fertile wealthy women of their time, they did not suffer from the appalling fecundity of annual births or the futility of frequent infant burials. Economically, these women often had husbands who were in contact with London and other cities, and socially they were in a position to pass on the knowledge of the availability of nurse children. It seems likely that the knowledge that "prolonged suckling hindereth propogation" may also have been passed on from mother to daughter or daughter-in-law, even though William Petty, who wrote those words, had not then been born..$^{35}$

Sceptical demographers may be suspicious about Richard and Anne Smythe and their family reconstitution. In this case, there is no need. Smith/Smythe was not a common surname in Chesham and this Richard Smythe the glover and Anne his wife are unambiguously the couple who were married on 27 November 1564, and whose marriage was terminated by the death of Anne Smythe, wife of Richard Smythe the glover, on 7 November 1602. On each occasion when Anne lost an infant, another conception quickly followed. Hugh, her first child, was baptised on 30 June 1566 and buried ten weeks later. Elizabeth was baptised one year after Hugh was buried and married Robert Gibson of Aston Clinton on 27 June 1603. Elizabeth was then thirty-six years old, and it is not insignificant that her mother had recently died and her father had remarried. Richard and Anne Smythe's third child, Mary, was baptised on 29 September 1569. She is their only child not accounted for. Mary may have left the parish or have been buried under a husband's name. There is no record of her marriage, but members of this family were far from parochial in their choice of marriage partners. William, the fourth child, was baptised on 20 April 1572 and married Amy Clerke of Great Tring in 1593. Thomas, the penultimate child, was baptised on 7 August 1580 and buried on 2 April 1581. Eleven months later the youngest child, Jane, was baptised, and she married Armiger Eevens of Hendon in Middlesex in 1603 . We have noticed that Hugh, the first child, did not survive, but after rearing two girls and a boy between 1567 and 1572, Anne Smythe probably started taking in nurse children. If she did so, she was successful in rearing them; at least none was buried in Chesham until March 1578. If any children were conceived by Richard and Anne Smythe between 1572 and 1579 they were not baptised in Chesham. On 19 March 1578, "margarite a nurse child of London nursed by the

\footnotetext{
${ }^{25}$ McLaren, op. cit., note 2 above, p. 380; also for Petty see Craig, op. cit., note 31 above, p. 6, "every child, rich and poor, above seven years of age should have opportunities for education ..." because such opportunities did not exist many were "holding the Plough which might have been made fit to steer the State"; and from Allen G. Debus (editor), Medicine and health in seventeenth century England, Berkeley, Los Angeles, and London, University of California Press, 1974, p. 383, "a most rare and exact anatomist ... of a sweet and natural disposition .... As for solid judgement and industry, altogether masculine". The attitudes and understanding of William Petty (1623-1687), do indeed appear to be rare for a man of his time with regard to children and nursing.
} 


\section{Nature's contraceptive}

wyfe of Ric. Smyth", was buried. On 26 June "Katherine a nurse child of Richard Parkes of London and nursed by the wyfe of Ric. Smyth"36 was buried, and on 5 July, "marc sonne of one hawsefoote of London and nursed by the wyfe of Ric. Smyth", 37 was buried. Soon after "marc hawsefoote" was buried, Anne became pregnant, although she had probably avoided a pregnancy for seven years. Thomas, her own child, as we have already noted, did not live, and the last child to be born to Richard and Anne Smythe was baptised eleven months later on 26 February 1582. This child lived, but perhaps Anne was not going to take any chances on further pregnancies. We do not know when he came to her, but on 7 December 1583, John, the son of John Porter of London and a nurse child of the wife of Richard Smyth, was buried. Anne may have been nursing John Porter and her own daughter Jane at the same time. Many women are capable of nursing more than one child and one woman has been known to nurse seven at the same time. ${ }^{38}$ Perhaps one ought to say that Anne Smythe buried four and a half nurse children, because on 26 March 1585 , "Jaane daughter of Robert white of London, nursed first by the wyfe of Adrian Goodchild and lastly by Ric. Smythes wyfe"39 was buried. It is impossible to say if Anne Smythe neglected her charges or was incapable of feeding them properly. She was able to rear four out of her own six children, three of them, as we have seen, were married in the parish. All that can be said is that there does not seem to have been an epidemic from the distribution of the burials, but in the calendar year 1578 three of the twenty-four people who were buried in the parish of Chesham were the nurse children of Anne, the wife of Richard Smythe, the glover. It is possible that an infectious disease was brought from London to the Smythe household by the first nurse child, who died in March 1578. If this was so it did not spread in the parish like the epidemic we shall note later.

On 9 March 1577, "Wm a nurse [child] of London nursed by Adrian Goodchildes wyfe", 40 was buried. Adrian Goodchild was married to Joan Smyth on 28 April 1575. Unfortunately Joan cannot be proved to have been related to Richard Smythe the glover, but she may have been his sister. Joan and Adrian Goodchild baptised two children, Nicholas on 23 September 1576, and Samuel on 21 July 1583 after an intergenesic interval of almost seven years. We cannot tell how many, if any, children were nursed by Joan Goodchild during this period, but we do know that she buried a child she was nursing on 19 March 1578. Her own son Nicholas was buried on 9 October 1581. Samuel, her second child, was buried at the age of eighteen months on 15 January 1585. Perhaps she took a nurse child immediately after Samuel was buried. Whatever happened, she did nurse a strange child but as already noted, Jaane White was taken over by Richard Smythe's wife and buried on 26 March 1585 . Quite clearly Adrian Goodchild's wife could not cope with the situation, and on 12 May 1585, "John Gallopp a nurse child of London nursed by the wyfe of Adrian

${ }^{20}$ Garrett-Pegge, op. cit., note 33 above, p. 260.

82 Ibid.

38 Ronald S. Illingworth, The normal child, Edinburgh and London, Churchill Livingstone, 1975, "A wet nurse is known to have produced $5,770 \mathrm{ml}$. of milk in one day, and was able to maintain seven babies at a time with the quantity produced" (p. 10).

${ }^{30}$ Garrett-Pegge, op. cit., note 33 above, p. 266.

40 Ibid., p. 267. 


\section{Dorothy McLaren}

Goodchild",41 was buried. On 12 June 1587, Joan Goodchild was herself laid to rest. Adrian soon married again, but there is no evidence that the second Mrs. Goodchild took in any nurse children.

Henry Gosham was a miller, his wife bore seven children between their marriage on 21 October 1576 and the baptism of their last child Henry on 15 February 1598. This was a period of good registration and seven children in twenty-two years, before artificial contraception, cannot be called appalling fecundity. The first four children appear to have survived. Jane and Henry Gosham buried their fifth and their sixth children in infancy. The sixth, Simon, was buried on 23 April 1593, and ten months later, "Edward Tarr Sonne of an haberdasher of London and nursed by the wyfe of Henry Gosham",42 was buried. Jane may have taken other nurse children who survived. Her last pregnancy did not commence until the spring of 1597 , but an intergenesic interval of three years at the end of the child-bearing period with or without contraception by any method would not be inconsistent with what is known of child-bearing patterns.

Zachery Gosham's date of marriage is not known, and it is possible that it was not a first marriage for him or his wife. Their daughter Priscilla was baptised on 18 August 1588 and buried in December of the same year. In March 1589, "Mary Roper of London nursed by the wyfe of Zachery Gosham", was buried. Another nurse child of the wife of Zachery Gosham was buried on 24 January 1590. Anne, the second child of this marriage, was baptised on 26 July 1590. It seems that Elizabeth, the wife of Zachery, conceived before the death of the nameless nurse child who was buried on 24 January 1590. It has never been claimed that all women who prolong the breast feeding of their infants are infertile, and it is possible that this child was being partially weaned, which would undoubtedly increase the likelihood of ovulation.

John Ketch, another wood-turner, married Katherine Edwards who was related to the wood-turning, wet-nursing Edwards families. John and Katherine Ketch produced five healthy children with approximately a two-year gap between each of them. There is no ambiguity about this family, and we know that the children survived because we have the marriage records of each and every one of them in the parish. It is again quite impossible even to hint about the total number of nurse children who may have come to Katherine Ketch after the baptism of her last child Joan on 28 February 1597. What we can say is that she buried, "Ellen the daughter of Tho. Kyngston of London"43 on 21 February 1598 and "William Palmer a nurse child from London nursed by the wyfe of John Ketch turner", 44 on 23 November 1608. The last entry is, of course, not within the period of analysis and therefore not included in the table. All five of the natural children of John and Katherine Ketch were taken to the Chesham altar, not a bad batting average in the infant mortality stakes. Moreover, Katherine Ketch, who was married just before her twentyfifth birthday, was not burdened with a lifetime of pregnancies. Her marriage of almost twenty-eight years ended when John was buried in 1614, seventeen years after

41 Ibid.

42 Ibid., p. 276.

is Ibid., p. 281.

4 Ibid., p. 296. 


\section{Nature's contraceptive}

their last child had been baptised.

Thomas Dell, a tiler by trade, married Joyce Penless on 3 November 1572 and nine children were born in twenty years, the highest number of baptisms to a family in the sample. Two children were buried within months of each other in 1583, although they appear to have been successfully weaned. The fifth child, Mary, was baptised on 18 February 1585 and buried four days later. Another delivery followed within sixteen months, although the previous five intervals had been a regular two and a half to three years. The seventh child Noe [sic] was buried two months after baptism and again a quick pregnancy followed with the delivery of Hugh, thirteen months after Noe was buried. Hugh, the penultimate child, survived and the last intergenesic interval for Joyce Dell was almost three years. It might have been possible for this family to have had less conceptions. By 1586 three sons had survived infancy and in December 1587, "Mary, daughter of Gerard Price of London and nursed by the wfye of Thomas Dell tyler"45 was buried. Had Gerard Price's daughter lived, little Noe might never have been conceived, delivered, or buried.

Robert Dyllam married Phillis Randoll on 30 January 1579. As already noted, the Randoll family did take nurse children, but their common christian names made family reconstitution impossible. Not so the Dyllams. All the entries for this family may be used, and the burials of both of the parents are recorded in the Chesham register. Five children were baptised. Perhaps because they had four healthy children, Phillis and Robert Dyllam took a nurse child which was buried on 18 October 1590. Perhaps they also took others who did not die. Anne, their last child, was baptised on 23 December 1593. Five children were baptised in the first twelve years of a twentyyear marriage which ended with the death of Robert in 1608. In fact, his widow Phillis lived on for a further twenty-two years.

What we have so far described was evidently the child-bearing pattern for almost all of the families in the sample of teeming women of Chesham who buried a nurse child between 1578 and 1601. One family does not follow this pattern. Richard Gatte of the "corner house Whealpleyhill", married Agnes Clerk, a servant, on 16 November 1579. There was either a pre-nuptial pregnancy or a premature birth. The first baby arrived at the font on 24 July 1580 . Six children followed in six years, but only one of them succumbed to perinatal mortality. Three more children followed, making the Gatte family equal with the Dell family in recording the highest number of baptisms, but evidence of a nurse child is not to be found in the Gatte family until three boys and three girls had been baptised. These first six baptisms took place annually, but the next three intervals were all about three and a half years. It does not look as though Agnes was always suckling her infants, unless she was one of those rare women who conceive whilst fully breast feeding. It is possible that after six close pregnancies, if she had not been suckling the early infants, she decided to do something about her fecundity. I think that she may have suckled Sara, her seventh child, and when Sara was weaned she took another to nurse. Thomas Hill, a nurse child of the wife of Richard Gatte was buried on 4 December 1591. Richard married again after Agnes was buried on 28 May 1600. His second wife also took nurse children, but they do not come into the period under review. There is evidence

${ }^{45}$ Ibid., p. 270. 


\section{Dorothy McLaren}

for merchants' wives emulating gentlewomen, was Agnes Gatte perhaps reversing the pattern $?^{46}$ Unfortunately, the occupation of Richard Gatte is not known, but they did keep many servants during the period. They may have been wealthy and if so Agnes would not have been the first wealthy woman to have changed her infant feeding habits halfway through her child-bearing period. Alternatively, if she was of humble birth, she may initially have tried to emulate her rich employers' wives, but after six pregnancies returned to the safer custom of her peers.

Two more families will be discussed qualitatively. Robert Birch and Margaret Hawkes were married on 18 September 1595 . He was a shovel-maker, sometimes called trencher-maker, and had nominal links with other wood-turners in family and in service. Although the marriage was recorded on 18 September 1595, there is no evidence of a child being born until the baptism of Cecily on 20 August 1600 . It is likely that one or more pregnancies occurred before Cecily was born. However, any live-born children are likely to have perished in 1610 or 1611 , when there was a crisis mortality in Chesham. It is customary to note crisis mortality in families at certain times, but seldom does one find a mother so bereft as Margaret Birch. Between 1600 and 1608, Robert and Margaret Birch baptised five children, all of whom seem to have survived infancy. During the years 1610 and 1611 however they were all buried. Three more of their children, whose baptisms are not recorded in the Chesham register and may have been born before Cecily in another parish, were also buried during these years. Due to the ambiguity of their records the Birch family is not included in the sample proper. Robert and Margaret Birch also buried, "Samuel Bates, a nurse child" on 19 March 1611. If plague or typhus did not strike down the Birch children and foster child, something equally disastrous did, and in October 1611, Robert Birch himself was buried. Margaret Birch, née Hawkes, survived the deaths of her husband, eight of her own children, and at least one child at nurse to her. Margaret then married William Coleman in 1612 when she was forty years old. Two children were born. After the baptism of Elizabeth, the second child, nothing further is heard of this family in Chesham. Perhaps Margaret could not bear to stay in the parish where her first husband and eight of her children had perished.

The Birches were not the only family to suffer ghastly mortality in 1610 and 1611 . Henry and Joan Awby reared their own family and took nurse children in the last quarter of the sixteenth century in Chesham. Henry was referred to as "deceased" by 1598, but he must have died between the burial of his last daughter Alice on 18 February 1593 and the marriage of his widow, Joan, to Henry West on 7 October 1596. Henry and Joan West are not included in the foster family sample as they buried no nurse children. They baptised four children between July 1597 and June 1606. The first child of this marriage, Margaret, was buried less than eighteen months after her baptism. The other three were reared successfully until the spring of 1611 , when, like the Birch children, they perished within days of each other. This time the

\footnotetext{
46 Agnes Gatte's family reconstitution starts like that of a typical gentlewoman of her time, who would have sent her children to wet-nurse, rather than one who was suckling her own babies. Halfway through her maternal experiences the pattern changes; like Alice Thornton, whose diary clearly shows that she decided to feed her own son Robin when previous children who had been wet-nursed had died. McLaren, op. cit., note 2 above, p. 386.
} 


\section{Nature's contraceptive}

mother died with them. Hardly a week passed in the spring of 1611 without a child or nurse child of the Birch or West families being taken to the churchyard at Chesham. ${ }^{47}$

Leaving aside epidemics and famine conditions, poor mothers and infants may have been healthier than wealthy mothers and infants in "The world we have lost", especially in rural environments. In the eighteenth century it was thought by some that the refusal of a woman to suckle her own baby was so great a deviation from the law of nature that it was responsible for the poor health of a newly-delivered mother, "who frequently incurs by this fashionable act of imprudence the risk of her own life, as well as that of her child". ${ }^{48}$ Research regarding the reduction of the intergenesic interval whenever an infant died within the first two years of life indicated that noble and gentle women in pre-industrial England generally produced and lost far more infants than rural poor women. Yet it seems to be taken for granted, and book after book on the subject repeats the belief, that "the poor fared worse". ${ }^{49}$ It is a big jump to consider, that, aside from famines and epidemics, because they were poor and because they were closer to the soil, rural mothers and infants were probably physically and psychologically more healthy than upper-class mothers and infants. Historians need caution when dealing with probabilities; however, it is undeniable that poor rural mothers were much closer to the normal life-history of our species than their wealthy contemporaries. It would seem that, until evidence is produced to show that the poor did indeed fare worse in these matters, it would be better to leave them out of discussion in history textbooks.

It is well known that in the past children were sent away from home whilst very young. No doubt many upper-class folk thought it was in the best interests of their children to have them leave the nest at an early age, but not all mothers were happy about it. ${ }^{50}$ The evidence for the age at which the poor children left home is quantitative

\footnotetext{
17 It is noteworthy that in the busy port of Minehead, Somerset, the burials for April 1611 were more than treble the normal, and the year was clearly one of crisis mortality. Like Chesham, the burials were clustered in families in 1610 and 1611 . These are not generally regarded as plague years, but Carlo Cipolla starts his book Cristofano and the plague (London, Collins, 1973) with the words, "Between 1613 and 1666, Europe was devastated by a dreadful series of plague epidemics. According to George Sticker, the epidemics of 1615-1635 were part of a cycle that he labelled, 'Indian' because of its possible origin in India in 1611" (p. 15).

${ }^{48}$ Roscoe, op. cit., note 4 above, preface to the 1789 edition.

19 L. A. Clarkson, The pre-industrial economy in England 1500-1750, London, Batsford, 1971, pp. 236-237. B. Saunders, John Evelyn and his times, Oxford, Pergamon Press, 1970, pp. 64-66. Stone, op. cit., note 7 above, p. 64. Professor Stone has drawn a picture of progress from a society of brutish attitudes to one of caring. The picture may not be true to life, "Unfortunately, anyone who looks carefully at the diaries, autobiographies, personal papers, ecclesiastical and other court records, and village sources for the period from 1400-1700 will find that Stone's general picture does not seem to fit the evidence at all well", Alan Macfarlane, 'Some psychological consequences of English individualism, 1400-1700', Bull. Soc. social. Hist. Med., 1978, 22: 5-8. Derek Jarrett, England in the age of Hogarth, St. Albans, Paladin, 1976, pp. 59-60, has quoted a contemporary view of William Cadogan, physician in 1754, about the "healthy fecundity of the poor", but infanticide and neglect is stressed from shaky evidence. "Good mothering is an invention of modernization", Shorter, op. cit., note 29 above, p. 168, is a premature, wild speculation.

${ }^{50}$ See note 25 above, and from the mother of Henry Acland when he was five years old, "I do not doubt but I should have heard from you had you been able to write, but you are not yet old enough to learn .... We have often wished you were here. ... . Now goodnight little Henry, Papa sends his love, and we both wish you to kiss Leopold for us. Henry had a younger brother Leopold. Dept. Western MSS, Bodleian Library, Oxford, Acland D.37.
} 


\section{Dorothy McLaren}

and lacks detail. From parish records it is clear that eight years old was not at all an uncommon age for poor children to leave their parents. The boys and girls of peasants and tradesmen sometimes went to relatives, but often to establishments without social or economic ties with their parents. Evidence for the poor leaving home at a much earlier age is lacking. Some poor children, however, had to be reared by others, and of course some were abandoned. Unless disaster overtook the parents there was no real need for a poor child to leave home until he was apprenticed. No need, therefore, for him to be deprived of the parental bond which most people today regard as important. Some wealthy mothers who did send their children away may have been ill or may have had insufficient milk. Some mothers may not have understood how to suckle their infants. Some may have had no inclination to do so, and some could not, because, "By a certain absurd custom, which has often prevailed, and may soon prevail again in this island, the nipple of the female breast is frequently so depressed, as to render it, throughout life, totally unfit for the purpose for which it was by nature intended, and the mother, though enjoying a strong and healthy constitution, and with the sincerest disposition to perform this first duty to her offspring, finds herself debarred of this pleasure, and perhaps irreparably injured in her health, from the effects of this worse than barbarous fashion". ${ }^{51}$ Clearly, the statement that, "the poor fared worse", needs reassessment, certainly as far as maternal matters are concerned.

When home conditions were healthy and the amenorrhoea of famine which inhibits conceptions was reduced, by way of increased agricultural production, there was an increase in the numbers born and an increase in the numbers of those who survived. This led to great population growth. When considering factors that contribute to population growth and industrialization in England, the abandonment of prolonged lactation ought to be added to causes like clean clothes, sanitation, better diets, and vaccines. The picture of the Victorian poor woman with a dozen infants in as many years, trying to be home-maker and child-bearer, as well as breadwinner, ${ }^{52}$ is not portrayed in pre-industrial England. This picture only emerges after poor women had to abandon suckling to work in mine, mill, or sweat shop. They had to abandon both suckling their own infants at an early age, and the wet-nursing customs that had combined to keep their fertility down in the past.

Work in south Oxfordshire and north west Somerset during the Stuart period indicates a mode of long, regular spacing of births for the poorer sort of teeming women. ${ }^{53}$ It would have been neat to have found clear evidence for prolonged lactation by wet-nursing in these areas. History does not work like that. The clear evidence emerged in Chesham, Buckinghamshire, at the end of the Tudor period. The custom may have been universal, the facts await exploitation. If the contraceptive properties

s1 Roscoe, op. cit., note 4 above.

52 The Guardian, 9 February 1978, picture and article on Victorian poor women. I am indebted to Maureen McMurtry for this reference.

${ }^{38}$ The modal class of birth intervals of two to three years was found in Japan, and accepted by the writers to indicate prolonged lactation rather than infanticide or stillbirths. Susan B. Hanley and Kozo Yamamure, Economic and demographic change in pre-industrial Japan, 1600-1868, Princeton University Press, 1977, p. 244. 


\section{Nature's contraceptive}

of the custom are as reliable as we suspect, we need look little further for high increases in birth rates during industrialization. It has been suggested that a prime factor in determining smaller families for the poor was poor diet. We should not ignore this factor, but we know that many Victorian poor women went to bed hungry: not sufficiently undernourished, however, to prevent conception taking place. Comparison of the number of children born to Elizabethan and Victorian poor women, indicates that abortion, infanticide, coitus interruptus, and poor diet has played a part in the size of the poor pre-industrial family. The chief determinant, however, in family limitation before good artificial contraception appears to have been prolonged lactation and wet-nursing, often combined.

Three hundred years have passed since William Petty said that prolonged suckling hindered propagation. It has been said that an increase in fertility was an impossible cause of high population growth, because fertility was as high as it could be in preindustrial England..$^{54}$ This statement has not gone without criticism. ${ }^{55}$ High fertility was true as far as wealthy women were concerned. For the majority, it was as William Petty suggested. Many more infants could have been born, because as Professor R. V. Short said in a recent address to the Royal Society, "Throughout the world as a whole more births are prevented by lactation than all other forms of contraception put together". ${ }^{58}$

54 Thomas McKeown, The modern rise of population, London, Edward Arnold, 1976.

${ }^{55}$ Brian Benson, 'A review of The modern rise of population', Loc. popul. Stud., 1976, 17: 44-47, "McKeown . . . can be faulted for not using some information he could have had. Information, however, that might have countered his case. In assessing the role of fertility in the eighteenth century expansion, for example, the author contends that a rise in fertility could not have occurred simply because fertility behaviour was already unrestricted and had always been so, and that therefore birth rates were at their maximum and could rise no further."

${ }^{66}$ R. V. Short, 'The evolution of human reproduction', Proc. R. Soc., Lond. series B, 1976, 195: 3-24. I owe this reference to Dr. Jane Evans, Division of Genetics, Department of Paediatrics, Childrens Centre, Winnipeg, Manitoba, Canada. 